\title{
Trends and Challenges in Regional Life Cycle Management: A Bibliometric Analysis
}

\author{
Alberto Bezama ${ }^{1, *(1)}$, Nora Mittelstädt ${ }^{1}$, Daniela Thrän ${ }^{1,2}$ and Fritz Balkau ${ }^{3}$ \\ 1 Department of Bioenergy, Helmholtz Centre for Environmental Research-UFZ, 04318 Leipzig, Germany; \\ nora.mittelstaedt@ufz.de (N.M.); daniela.thraen@ufz.de (D.T.) \\ 2 Bioenergy Systems Department, Deutsches Biomasseforschungszentrum (DBFZ), 04347 Leipzig, Germany \\ 3 Sustainable Solutions, 75004 Paris, France; fbalkau@gmail.com \\ * Correspondence: alberto.bezama@ufz.de; Tel.: +49-341-243-4579
}

check for updates

Citation: Bezama, A.; Mittelstädt, N.; Thrän, D.; Balkau, F. Trends and Challenges in Regional Life Cycle Management: A Bibliometric Analysis. Sustainability 2021, 13, 10335. https://doi.org/10.3390/ su131810335

Academic Editor: Adriana Del Borghi

Received: 9 July 2021

Accepted: 14 September 2021

Published: 16 September 2021

Publisher's Note: MDPI stays neutral with regard to jurisdictional claims in published maps and institutional affiliations.

Copyright: (c) 2021 by the authors. Licensee MDPI, Basel, Switzerland. This article is an open access article distributed under the terms and conditions of the Creative Commons Attribution (CC BY) license (https:// creativecommons.org/licenses/by/ $4.0 /)$.

\begin{abstract}
Life cycle management has become increasingly important in the formulation of regional sustainable development policies and programs, while research on and the application of life cycle assessment (LCA) methodologies are predominantly conducted in a business context or for materials and product-related issues. In light of the growing importance of regional policymaking, this article discusses the current scientific landscape of regional life cycle management approaches. It conducts a bibliometric analysis using the Scopus database and integrates a co-word analysis to highlight important linkages. Our analysis reveals that an increasing number of papers have been published on regional-level LCAs in recent years; however, they remain focused on issues related to the traditional materials-oriented aspects. Conversely, little research appears to be conducted on regional life cycle management issues and activities. The research is strongly centralized, with a clustering of regional LCA studies within a relatively small group of countries, institutes, journals and authors. Despite a rapid increase in recently published papers, our analysis reveals a gap in research and knowledge transfer of regional LCA results to public policymakers and regional planners.
\end{abstract}

Keywords: regional life cycle management; regional life cycle assessment; bibliometric analysis

\section{Introduction}

As has been the case for corporations, research institutions and professional associations for years, public authorities are increasingly being confronted by complex decisionmaking processes in a fast-developing political, economic and social environment [1-4]. The increasing responsibilities and budgets of regions in various countries demand integrated responses if they are to truly deliver on their often high-profile sustainability objectives. Nevertheless the current management approaches, based as they are on singleissue policies and programs, often struggle to deal effectively with the complex agendas they face [5]. Interconnected regional issues and problems require a more holistic approach that takes into account entire life chains and which cuts across multiple sustainable development goals (SDGs). At the same time, complex social and intergenerational issues must also be considered [6,7].

Sustainable regional development depends on the adoption of systematic and longterm decision-making criteria at different levels. In recent years, life cycle approaches have emerged as the most effective framework within which such tools can be applied in order to ensure that the key SDGs are properly considered [8-12]. However, the use of various life cycle tools for regional sustainability management is still evolving and suffers from a lack of general awareness about them and experience in using them [13,14]. In order to understand this issue, it is important first to clearly distinguish between life cycle assessment (LCA) as the analytical phase and life cycle management (LCM) as the phase of interventionist actions, whether in policy or on the ground. In the case of the former, LCA techniques identify the impacts of the current situation (i.e., the "problems") and 
the various alternative options (i.e., the "solutions"). On the other hand, LCM should be understood as providing a life-chain-based approach to intervention, federating the stakeholders along the resource or material life cycle around agreed upon objectives in order to achieve a more sustainable system outcome that optimizes the benefits and impacts along the entire life-chain and across all SDGs [15].

In terms of methodological developments, regionalized life cycle approaches started to gain the attention of researchers in the early 2000s when they were faced with the challenges of introducing characterization factors in life cycle approaches for assessing site-specific environmental effects, as well as the effects on humans to the exposure of chemicals in the environment [16-20]. Today, the development of such methodological approaches faces challenges in terms of data availability, lack of standardization, insufficient quantification of uncertainty factors, as well as inconsistent metadata and data formats, as concluded by a survey carried out by the UNEP/SETAC Life Cycle Initiative and presented by Mutel et al. [21]. Nonetheless, as regionalized LCA approaches are built on the basis of a material flow analysis structure, they can be used to account for material and energy streams, as well as for social and socioeconomic parameters, which are extremely relevant at a local and regional level. The use of regionalized approaches can, therefore, certainly help feed local/regional information into decision-making support systems that are designed to assist regional managers.

While a number of LCA methodologies (e.g., LCA, organizational LCA (O-LCA), environmental product declaration (EPD) and carbon footprints) have been standardized under ISO 14000, these are mostly applied in the corporate sector to improve products or to develop management approaches [22-24]. Territorial LCA, biodiversity issues and social LCA, on the other hand, are beset by complexities that hinder their widespread use. Others, especially life cycle management tools, still await standardization and are applied according to widely differing metrics [25-27]. Procedures such as public procurement, which would appear at first sight to be eagerly awaiting life-cycle-based decision making, are still subject to the vagaries of individual choices based on supposed virtues and faults that often reveal a strong single-issue bias [28,29].

A few initiatives have been undertaken to assist individual regions in applying life cycle-based management approaches (for example, the Life Cycle Summer School organized annually by FSLCI [30], as well as the EU-funded project "LCA4Regions" [31]), while international institutions such as the European Union, OECD and UNEP have limited themselves to simply promoting the advantages of such an approach in the context of other initiatives, such as resource efficiency, the circular economy or public procurement. Often, these programs have themselves been sector-focused, for example, on the circular economy (e.g., the Ellen MacArthur Foundation [32]), on sustainable procurement (e.g., the OECD and UNEP programs [33-35]) or on product standards and regulations.

In such a slowly evolving situation, it is interesting to try to reconcile current LCA practice with actual usage at the regional level to see if and how the situation can be improved, i.e., to see the extent to which regions rely (or not) on life cycle methodologies that are often already commonly used in other sectors [36-38]. Such a baseline investigation would allow regions and other institutions to benchmark their efforts and successes against others, thereby stimulating some horizontal learning. At the same time, it would enable them to build bridges to the more frequent life cycle initiatives in the corporate sector.

In this regard, bibliometric analyses of online literature databases emerged in the 1970s and have been described as a "quantitative analysis of the bibliographic features of a body of literature" [39].

The goal of this publication is to investigate the scale of research on regional LCA applications in support of sustainable development, both at the policy and program level. This is done through a bibliometric analysis of regional life cycle initiatives to identify the number of papers published on this subject, the principal sources of such papers and the specific subject focus. This mapping of research will eventually lead to a more detailed analysis of the significance of existing research by pinpointing strengths and weaknesses, 
possibly stimulating further surveys, and investigating interesting features that might lead to an enhancement of LCA practices in the regions themselves.

\section{Materials and Methods}

\subsection{Bibliometric Analysis Method}

Bibliometric analysis methods have the bibliometric characteristics of research fields as their object of research. Science mapping methodologies help to create insights into the size, publication evolution, global dispersion and global trends of research publications of a certain knowledge base. The use of bibliometric analyses allows researchers to analyze larger datasets than typical reviews [40,41]. They can also enable the creation of a structural overview in a certain field [42].

Several bibliometric analyses have been conducted in the LCA context: The knowledge diffusion path and collaboration networks have been described by De Souza and Barbastefano [43]. LCA-related publications in the WoS database have been analyzed by Chen et al. [44]. Research has been published about trends and geographical hotspots of LCA-related research [45], the role of the visibility of LCA studies in bibliometric research [46], research trends and the author-keyword co-occurrence development of LCA publications [47].

\subsection{Data Source and Review Strategy}

The bibliometric analysis was carried out using the online bibliographic database Scopus as the source of the data for the study. Since fewer journals are indexed in the Web of Science Core Collection (WoS CC) than in the Scopus database [48] and preliminary search attempts on WoS CC resulted in the identification of fewer publications, we decided to exclusively focus on the Scopus database in our analysis. In order to avoid any biased analysis and because of the limited number of scientific papers published directly in the field of regionalized life cycle management, all types of scientific publications, with the exception of errata, were selected in the Scopus database.

Table 1 shows the research framework used for the analyses and provides details on the concepts and terms that will later be used to define the search queries for the literature review.

Table 1. Overview of the concepts and terms used to conduct the bibliometric analysis.

\begin{tabular}{|c|c|}
\hline Category & Concepts and Terms \\
\hline LCA methods in a regional context & $\begin{array}{ll}\text { - } & \text { Life Cycle Assessment (LCA) in a regional/spatial/territorial/local context } \\
\text { - } & \text { LCA in a regional/spatial/territorial/local context } \\
\text { - } & \text { Life Cycle Management (LCM) in a regional/spatial/territorial/local context } \\
\text { - } & \text { Life Cycle Methodology in a regional/spatial/territorial/local context } \\
\text { - } & \text { Life Cycle Sustainability Assessment (LCSA) in a regional/spatial/territorial/local or case study context } \\
\text { - } & \text { Material Flow Analysis (MFA) in regional/spatial/territorial/local or case study context } \\
\text { - } & \text { MFA and Circular Economy in a regional/spatial/territorial/local context } \\
\text { - } & \text { Organisational Life Cycle Assessment (O-LCA) } \\
\text { - } & \text { Life Cycle Costing (LCC) in a regional/spatial/territorial/local context } \\
\text { - } & \text { Life Cycle Thinking in a regional/spatial/territorial/local context }\end{array}$ \\
\hline LCA in specific contexts & $\begin{array}{l}\text { - } \quad \text { LCA and agriculture and cultivation } \\
\text { - LCA and (specific) sector (e.g., building sector, e-mobility) } \\
-\quad \text { LCA and land use } \\
\text { - } \\
\text { Life Cycle Costing }\end{array}$ \\
\hline Related approaches & $\begin{array}{l}\text { - } \quad \text { Environmental Product Declarations (EPD) } \\
\text { - } \quad \text { Regional ecological/sustainability footprints } \\
\text { - } \quad \text { Carbonal Wooter Footprint and green/blue/grey water footprint } \\
\text { - Sustainable Management in a regional/spatial/territorial/local context }\end{array}$ \\
\hline
\end{tabular}


In a further step, we conducted a review of software tools used for the bibliometric analysis. The analysis tool of Scopus was selected together with VOSviewer (for co-word analyses and graphical representation).

A list of search query wordings to cover the above terms was created and continuously adapted following several search attempts. After examining the list in more detail and checking the relevant literature, a series of "hidden LCAs" were identified, thus making it possible to extend the query wording list. Some query wordings produced no results at all and were eliminated from the research. As a result, the final list contains a total of 25 query wordings, as presented in Table 2.

Table 2. Final query wording for the bibliometric analysis.

\begin{tabular}{|c|c|c|}
\hline QW $\mathbf{N}^{\circ}$ & Description & Query Wording \\
\hline \multicolumn{3}{|c|}{ Category: LCA methods in a regional context } \\
\hline$\# 1$ & LCA in a regional/spatial/territorial/local context & $\begin{array}{c}\text { ((“life cycle assessment" OR “life-cycle assessment") W/15 } \\
\text { "region*”) }\end{array}$ \\
\hline \#2 & LCA in a regional/spatial/territorial/local context & $\begin{array}{c}\text { ((("life cycle assessment" OR “life-cycle assessment") W/15 } \\
\text { "territor*”) AND NOT ("national territor*")) }\end{array}$ \\
\hline \#3 & LCA in regional/spatial/territorial/local context & $\begin{array}{c}\text { (("life cycle assessment" OR “life-cycle assessment") W/15 } \\
\left.\text { "local }{ }^{* \prime}\right)\end{array}$ \\
\hline$\# 4$ & LCA in a regional/spatial/territorial/local context & $\begin{array}{c}\text { ((“life cycle assessment" OR “life-cycle assessment”) W/15 } \\
\text { "spatial*”) }\end{array}$ \\
\hline \#5 & $\mathrm{LCM}$ in a regional/spatial/territorial/local context & $\begin{array}{c}\text { ((“life cycle management") AND ("region*” OR “local” OR } \\
\text { "territor*” OR "spatial")) }\end{array}$ \\
\hline \#6 & $\begin{array}{l}\text { Life Cycle Methodology in a } \\
\text { regional/spatial/territorial/local context }\end{array}$ & $\begin{array}{c}\text { ((“life cycle methodolog*” AND ("region*” OR “local” OR } \\
\text { "territor*" OR “spatial*")) AND NOT ("computer" OR } \\
\text { "seism*" OR “coast" }) \text { ) }\end{array}$ \\
\hline \#7 & $\begin{array}{l}\text { LCSA in a regional/spatial/territorial/local or } \\
\text { case study context }\end{array}$ & $\begin{array}{l}\text { ((“life cycle sustainability assessment") W/15 ("region*" OR } \\
\text { "local" OR "territor" OR "spatial*" OR “case stud*")) }\end{array}$ \\
\hline \#8 & $\begin{array}{l}\mathrm{LCI} \text { in a regional/spatial/territorial/local or case } \\
\text { study context }\end{array}$ & 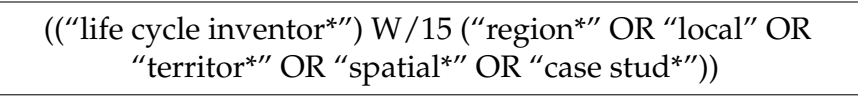 \\
\hline \#9 & $\begin{array}{c}\text { MFA/Management in a } \\
\text { regional/spatial/territorial/local context }\end{array}$ & $\begin{array}{l}\text { (("material* flow management" OR "material* flow analysis") } \\
\text { W/15 ("region*" OR "local" OR "territor" OR "spatial*")) }\end{array}$ \\
\hline$\# 10$ & $\begin{array}{l}\text { MFA and Circular Economy in a } \\
\text { regional/spatial/territorial/local context }\end{array}$ & $\begin{array}{l}\text { ("material* flow management" AND “circular econom*" } \\
\text { W/15 ("region*" OR “local" OR “territor*" OR "spatial")) }\end{array}$ \\
\hline$\# 11$ & Organisational Life Cycle Assessment (O-LCA) & $\begin{array}{c}(\text { ("organisation* life cycle assessment" OR “organisational } \\
\text { life-cycle assessment" OR “O-LCA") AND ("region*" OR } \\
\left.\left.\text { "local" OR "territor*" OR "spatial" }{ }^{* \prime}\right)\right)\end{array}$ \\
\hline$\# 12$ & $\begin{array}{c}\text { Life Cycle Costing in a } \\
\text { regional/spatial/territorial/local context (LCC) }\end{array}$ & $\begin{array}{l}\text { ("life cycle costing" W/15 ("region*" OR "local" OR } \\
\text { "territor" OR "spatial" }\end{array}$ \\
\hline$\# 13$ & $\begin{array}{l}\text { Life Cycle Thinking in a } \\
\text { regional/spatial/territorial/local context }\end{array}$ & $\begin{array}{c}\text { ("Life Cycle Thinking" W/15 ("region"* OR “local" OR } \\
\text { "territor" OR "spatial }{ }^{* \prime \prime))}\end{array}$ \\
\hline \multicolumn{3}{|c|}{ Category: LCA in specific contexts } \\
\hline$\# 14$ & $\begin{array}{c}\text { Life Cycle Assessment and agriculture and } \\
\text { cultivation (LCA) }\end{array}$ & $\begin{array}{c}\text { (("life cycle assessment" OR “life-cycle assessment") W/15 } \\
\left.\left.\text { ("agricultur" OR “cultivat" }{ }^{* \prime \prime}\right)\right)\end{array}$ \\
\hline$\# 15$ & $\begin{array}{c}\text { Life Cycle Assessment and (specific) sector (e.g., } \\
\text { building sector) }\end{array}$ & $\begin{array}{c}\text { (("life cycle assessment" OR “life-cycle assessment") W/15 } \\
\text { ("building*" OR “building sector")) }\end{array}$ \\
\hline \#16 & $\begin{array}{l}\text { Life Cycle Assessment and (specific) sector (e.g., } \\
\text { electric cars) }\end{array}$ & $\begin{array}{l}\text { (("life cycle assessment" OR “life-cycle assessment") W/15 } \\
\text { ("electric car*" OR "electric vehicle*" OR “e-mobility")) }\end{array}$ \\
\hline$\# 17$ & Life Cycle Assessment and land use & $\begin{array}{c}\text { (("life cycle assessment" OR “life-cycle assessment") W/15 } \\
\text { ("land use")) }\end{array}$ \\
\hline
\end{tabular}


Table 2. Cont.

\begin{tabular}{|c|c|c|}
\hline QW $\mathbf{N}^{\circ}$ & Description & Query Wording \\
\hline \#18 & MFA and policy application/measures & 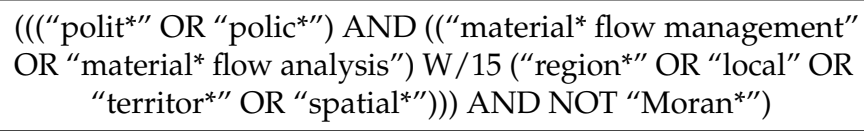 \\
\hline \#19 & $\begin{array}{l}\text { LCA in a regional/spatial/territorial/local context } \\
\text { and waste }\end{array}$ & $\begin{array}{c}\text { ((("life cycle assessment" OR “life-cycle assessment") W/15 } \\
\text { "waste") AND ("region*" OR “local” OR “territor*" OR } \\
\text { "spatial*")) }\end{array}$ \\
\hline$\# 20$ & Life Cycle Costing and Waste (LCC) & ("life cycle costing" AND "waste") \\
\hline \multicolumn{3}{|c|}{ Category: Related approaches } \\
\hline \#21 & Regional ecological/sustainability footprints & $\begin{array}{c}\text { ("regional* sustainab* footprints" OR "regional* ecological } \\
\text { footprints") }\end{array}$ \\
\hline \#22 & Environmental Product Declarations (EPD) & $\begin{array}{l}\text { ((“life cycle” AND (“Environmental Product Declarations" } \\
\text { OR “EPD”) AND ("region*" OR “local” OR “territor*” OR } \\
\text { "spatial*")) AND NOT ("pharma*” OR "molecular")) }\end{array}$ \\
\hline \#23 & $\begin{array}{l}\text { Regional Water Footprint and green/blue/grey } \\
\text { water footprint }\end{array}$ & $\begin{array}{c}\text { (("green water footprint" OR “blue water footprint" OR "grey } \\
\text { water footprint") AND ("region*" OR “local" OR "territor" } \\
\text { OR "spatial" }))\end{array}$ \\
\hline$\# 24$ & Carbon Footprint and Waste & ("carbon footprint" W/15 "waste") \\
\hline \#25 & $\begin{array}{l}\text { Sustainable Management in a } \\
\text { regional/spatial/territorial/local context }\end{array}$ & $\begin{array}{l}\text { ("sustainable management" W/15 ("region*" OR “local" OR } \\
\text { "territor*" OR "spatial*")) }\end{array}$ \\
\hline
\end{tabular}

QW: Query wording.

It should be noted that 'OR' was used as the main Boolean operator to cover different spellings and wordings. Furthermore, 'AND' was used for proofing purposes (correlation, localization). Field choices TITLE-ABS-KEY (=Topic) and TITLE (=Article Title) were used to identify the occurrence of a term in the article title or the topic (=article's title, abstract, keywords) of a scientific publication listed in the databases. The Boolean operator 'AND NOT' was used during the data cleaning process to exclude unrelated publications. Furthermore, the proximity operator ' $\mathrm{W} / 15^{\prime}$ ' was introduced to assure the correlation of two terms such as ("life cycle assessment" OR "life-cycle assessment") and "region*" (\#1) within the average proximity of one sentence (in this case, within a proximity of up to 15 words).

Data cleaning was performed during the compilation of the bibliometric data. The results were checked individually to avoid erroneous inclusions in the compilation due to homonymous terms or abbreviations. Abbreviations such as LCA were eliminated from the query wording due to a high overlapping outside the subject area, since, for example, it can also stand for "life cycle analysis", "landscape character assessment" and "land consolidation associations". In some cases, publications were manually discarded due to a weak correlation to regional LCAs or because the LCA or similar concepts were only part of the recommendations but not part of the core content of the article.

The timespan of the analysis was based on the first paper published on the research topic and was, therefore, narrowed down to 1976-2020 (including January 2021, since the input data for the analysis was collected on 3 February 2021 from the Scopus database). The authors have refrained from limiting the timespan in order to capture the temporal development of the publication activity.

Co-word analysis is a method that helps to identify key connections and clusters among research concepts. Visual mapping enables the cognitive structure of the research topic to be characterized [41]. In our study, the co-word analysis was performed using the Scopus database along with VOSviewer for co-word and cluster analysis as well as graphical representation. Only the first 13 query wordings (see Table 3) were used for the co-word analyses in order to include the papers found under generic queries and not the ones dealing with specific examples, as was the case for queries \#14 to \#25. Thus, query 
wordings which contained specification (2nd category) or which were linked mainly to related concepts (3rd category) were left out to avoid distorting the results.

Table 3. Results of the bibliometric analysis for the number of initial articles dealing with regionalized LCA approaches in the Scopus database, published between 1976 and 2020.

\begin{tabular}{|c|c|c|c|}
\hline QW No. & Description & $\begin{array}{l}\text { QW Appearance in the } \\
\text { Title of Publication }\end{array}$ & $\begin{array}{l}\text { QW Appearance as the } \\
\text { Topic of Publication }\end{array}$ \\
\hline$\# 1$ & LCA in a regional/spatial/territorial/local context & 117 & 440 \\
\hline$\# 2$ & LCA in a regional/spatial/territorial/local context & 11 & 25 \\
\hline \#3 & LCA in regional/spatial/territorial/local context & 30 & 204 \\
\hline$\# 4$ & LCA in a regional/spatial/territorial/local context & 29 & 103 \\
\hline \#5 & LCM in a regional/spatial/territorial/local context & 1 & 225 \\
\hline \#6 & $\begin{array}{l}\text { Life Cycle Methodology in a } \\
\text { regional/spatial/territorial/local context }\end{array}$ & 1 & 13 \\
\hline$\# 7$ & $\begin{array}{l}\text { LCSA in a regional/spatial/territorial/local } \\
\text { or case study context }\end{array}$ & 4 & 7 \\
\hline$\# 8$ & $\begin{array}{l}\text { LCI in a regional/spatial/territorial/local } \\
\text { or case study context }\end{array}$ & 54 & 214 \\
\hline$\# 9$ & $\begin{array}{c}\text { MFA/Management in a } \\
\text { regional/spatial/territorial/local context }\end{array}$ & 15 & 105 \\
\hline$\# 10$ & $\begin{array}{l}\text { MFA and Circular Economy in a } \\
\text { regional/spatial/territorial/local context }\end{array}$ & 0 & 1 \\
\hline$\# 11$ & Organisational Life Cycle Assessment (O-LCA) & 0 & 6 \\
\hline$\# 12$ & $\begin{array}{c}\text { Life Cycle Costing in a } \\
\text { regional/spatial/territorial/local context (LCC) }\end{array}$ & 3 & 24 \\
\hline$\# 13$ & $\begin{array}{l}\text { Life Cycle Thinking in a } \\
\text { regional/spatial/territorial/local context }\end{array}$ & 1 & 25 \\
\hline$\# 14$ & Life Cycle Assessment and agriculture and cultivation (LCA) & 163 & 583 \\
\hline$\# 15$ & $\begin{array}{l}\text { Life Cycle Assessment and (specific) sector } \\
\text { (e.g., building sector) }\end{array}$ & 432 & 1284 \\
\hline$\# 16$ & Life Cycle Assessment and (specific) sector (e.g., electric cars) & 65 & 145 \\
\hline$\# 17$ & Life Cycle Assessment and land use & 54 & 213 \\
\hline$\# 18$ & MFA and policy application/measures & 1 & 28 \\
\hline \#19 & LCA in a regional/spatial/territorial/local context and waste & 15 & 200 \\
\hline \#20 & Life Cycle Costing and Waste (LCC) & 6 & 208 \\
\hline$\# 21$ & Regional ecological/sustainability footprints & 8 & 22 \\
\hline$\# 22$ & Environmental Product Declarations (EPD) & 0 & 34 \\
\hline$\# 23$ & $\begin{array}{l}\text { Regional Water Footprint and } \\
\text { green/blue/grey water footprint }\end{array}$ & 20 & 257 \\
\hline$\# 24$ & Carbon Footprint and Waste & 71 & 462 \\
\hline$\# 25$ & $\begin{array}{l}\text { Sustainable Management in a } \\
\text { regional/spatial/territorial/local context }\end{array}$ & 91 & 1322 \\
\hline$\Sigma \# 1-\# 13^{a}$ & - & 266 & 1392 \\
\hline$\sum \# 1-\# 13^{b}$ & - & 261 & 1284 \\
\hline$\Sigma \# 1-\# 25^{\mathrm{a}}$ & - & 1192 & 6150 \\
\hline$\Sigma \# 1-\# 25^{b}$ & - & 1140 & 5747 \\
\hline
\end{tabular}

${ }^{\mathrm{a}}$ : contains duplicates; ${ }^{\mathrm{b}}$ : without duplicates. 


\section{Results and Discussion}

The final search (\#1-\#25) of the Scopus database resulted in 5747 publications, published since 1976, whose title, keywords or abstracts are related to the concept of regional LCA or related concepts (Table 3). Of these, 1140 publications refer directly in their title to the queried concepts in a broader sense.

It can be generally stated that the publications currently have no common terminology such as the term "regional LCA" or any other formulation. The bibliometric analysis shows that many wordings (regional/local/territorial/spatial) create a broad linguistic framework of the concept, with "regional" being the dominant term used in this regard. However, we found that there is no standard use or definition of the word "region", both with respect to legal entities and vernacular descriptions.

It is worth mentioning the numerous applications of LCA in the building sector (\#15), as well as in the agricultural sector (\#14,\#17). A minor relationship exists between MFA analyses and policy advice (\#28). Sustainable management in a regional context exhibits high publication numbers (\#25).

The results help to assess the production of scientific papers in the chosen research field. Using the Scopus database (5747 publications), the corpus was analyzed based on several bibliographic aspects. The results are presented in the sections below.

\subsection{Analysis of the Publication Activity}

The results show that the subject of regional LCA studies and related topics emerged in the mid-1970s in the scientific landscape when life cycle management was first mentioned. The article "Management of Privately Owned, Large On-Site Sewage Systems" by S. J. Steinbeck [49] is the first publication identified that explicitly mentions life cycle management. In contrast, the first publication in the corpus that explicitly mentions regional LCA is the 2006 article "Report on activity of Task Force 1 in the Life Cycle Inventory programme: Data registry-Global life cycle inventory data resources" by M.A. Curran [50].

Life cycle inventory approaches were first published in the mid-1990s. Since 2000, the number of publications has steadily increased. This increase in publications correlates (with a 1-year delay) with the introduction of the ISO standards for LCA (ISO 14040 and 14044) in 2006, providing a framework for LCA applications, life cycle inventory analysis (LCI) phases and life cycle impact assessments (LCIA). The highest rate of publication was in 2020. The cumulative progression in Figure 1 visibly illustrates the overall increase between 1976 and 2020.

Prior to the introduction of the ISO standards, regional LCA was a rarely discussed method that was included in very few publications. In the 1980s and 1990s, papers began being published that used life cycle costing methods.

In terms of the authorships of the published papers, some authors stand out in the collection of regional LCA studies, as presented in Table 4. An interpretation of their first names reveals that the authors are gender balanced. Most of the identified authors are tied to European institutes. Furthermore, it seems that a high concentration of activity is conducted at a relatively small number of institutes by a relatively small number of authors.

The Orcid and Scopus ID of the authors was added (where available) to assure that the authors were unambiguously identified in the database. The author's h-index was also added as an author-level metric to indicate the productivity and citation impact of the publications.

When assessing the institutional origin of the published papers, we found that some organizations have a prolific number of publications in the field of regional LCA, with the Chinese Academy of Sciences and ETH Zürich being the two most active institutions in this field worldwide, as presented in Table 5 . 


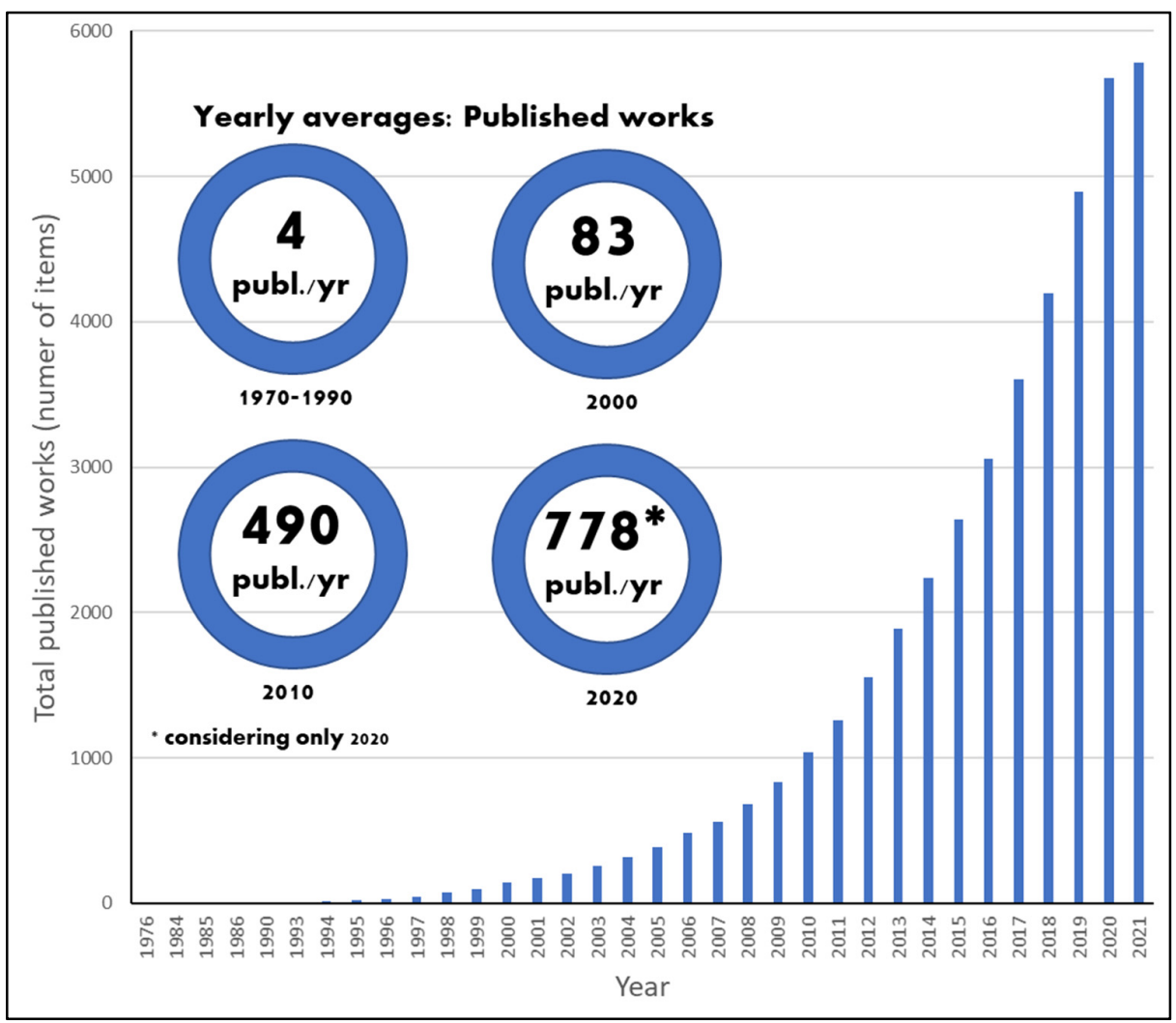

Figure 1. Cumulative number of published papers and yearly averages of published papers in the past four decades from 1976-2020, based on the results of the bibliometric analysis of the Scopus database carried out on 3 February 2021.

Table 4. Identification of the most prolific authors in the areas covered by the bibliometric analysis.

\begin{tabular}{|c|c|c|c|c|c|}
\hline Author Name & $\begin{array}{l}\text { Orcid ID and } \\
\text { Scopus ID }\end{array}$ & Author's H-Index & Current Affiliation & Country & $\begin{array}{c}\text { Number of } \\
\text { Publications }\end{array}$ \\
\hline Habert, Guillaume & $\begin{array}{l}\text { https: / / orcid.org/00 } \\
\text { 00-0003-3533-7896 } \\
\text { Scopus Author ID: } \\
8391064400\end{array}$ & 36 & ETH Zurich & Switzerland & 29 \\
\hline Bilec, Melissa M. & I & 25 & University of Pittsburgh & United States & 26 \\
\hline Hellweg, Stefanie & $\begin{array}{l}\text { https:// orcid.org/00 } \\
\text { 00-0001-6376-9878 } \\
\text { Scopus Author ID: } \\
\text { 6603550824 }\end{array}$ & 50 & $\begin{array}{l}\text { Swiss Federal Institute of } \\
\text { Technology }\end{array}$ & Switzerland & 26 \\
\hline Margni, Manuele & $\begin{array}{l}\text { https: / / orcid.org/00 } \\
\text { 00-0002-2475-0768 } \\
\text { / }\end{array}$ & 40 & Polytechnique Montreal & France & 25 \\
\hline Hollberg, Alexander & $\begin{array}{l}\text { https:/ / orcid.org/00 } \\
\text { 00-0002-9756-2362 } \\
\text { / }\end{array}$ & 9 & $\begin{array}{c}\text { Chalmers University of } \\
\text { Technology }\end{array}$ & Sweden & 21 \\
\hline $\begin{array}{l}\text { Moreira, Maria } \\
\text { Teresa }\end{array}$ & $\begin{array}{l}\text { https:// orcid.org/00 } \\
\text { 00-0001-9354-3298 } \\
\text { Scopus Author ID: } \\
26424779900\end{array}$ & 59 & $\begin{array}{l}\text { University of Santiago de } \\
\text { Compostela }\end{array}$ & Spain & 21 \\
\hline Feijoo, Gumersindo & $\begin{array}{l}\text { https:// orcid.org/00 } \\
\text { 00-0001-6231-3887 } \\
\text { Scopus Author ID: } \\
7003967670\end{array}$ & 60 & $\begin{array}{l}\text { University of Santiago de } \\
\text { Compostela }\end{array}$ & Spain & 20 \\
\hline
\end{tabular}


Table 4. Cont.

\begin{tabular}{|c|c|c|c|c|c|}
\hline Author Name & $\begin{array}{l}\text { Orcid ID and } \\
\text { Scopus ID }\end{array}$ & Author's H-Index & Current Affiliation & Country & $\begin{array}{l}\text { Number of } \\
\text { Publications }\end{array}$ \\
\hline Hoekstra, Arjen Y. & $\begin{array}{l}\text { https:// orcid.org/00 } \\
\text { 00-0002-4769-5239 } \\
\text { Scopus Author ID: } \\
\text { 7007050344 }\end{array}$ & 65 & University of Twente & Netherlands & 20 \\
\hline Allacker, Karen & $\begin{array}{l}\text { https:// orcid.org/00 } \\
\text { 00-0002-1064-0795 } \\
\text { / }\end{array}$ & 15 & KU Leuven & Belgium & 19 \\
\hline Landis, Amy E. & / & 26 & Colorado School of Mines & United States & 19 \\
\hline Nemecek, Thomas & $\begin{array}{l}\text { https:// orcid.org/00 } \\
\text { 00-0001-8249-1170 } \\
\text { Scopus Author ID: } \\
6506007033\end{array}$ & 28 & $\begin{array}{l}\text { Forschungsanstalt } \\
\text { Agroscope } \\
\text { Reckenholz-Tanikon }\end{array}$ & Switzerland & 18 \\
\hline Passer, Alexander & $\begin{array}{l}\text { https:/ / orcid.org/00 } \\
\text { 00-0001-8773-8507 } \\
\text { Scopus Author ID: } \\
\text { 53875067300 }\end{array}$ & 12 & $\begin{array}{c}\text { Technische Universitat } \\
\text { Graz }\end{array}$ & Austria & 18 \\
\hline Álvarez Antón, Laura & // & 1 & $\begin{array}{l}\text { GIRO Program, Institute } \\
\text { of Agrifood Research and } \\
\text { Technology, Barcelona }\end{array}$ & Spain & 17 \\
\hline Sala, Serenella & $\begin{array}{l}\text { https:// orcid.org/00 } \\
\text { 00-0003-1919-9948 } \\
\text { Scopus Author ID: } \\
\text { 55353253300 }\end{array}$ & 39 & $\begin{array}{c}\text { European Commission, } \\
\text { Joint Research Centre } \\
\text { (JRC) }\end{array}$ & Belgium & 17 \\
\hline $\begin{array}{c}\text { Gheewala, Shabbir } \\
\text { Hussaini }\end{array}$ & $\begin{array}{l}\text { https:// orcid.org/00 } \\
\text { 00-0002-4300-1551 } \\
\text { Scopus Author ID: } \\
\text { 6602264724 }\end{array}$ & 45 & $\begin{array}{c}\text { King Mongkut's } \\
\text { University of Technology } \\
\text { Thonburi }\end{array}$ & Thailand & 16 \\
\hline Pfister, Stephan & $\begin{array}{l}\text { https:// orcid.org/00 } \\
\text { 00-0001-8984-2041 } \\
\text { Scopus Author ID: } \\
\text { 26639761300 }\end{array}$ & 38 & ETH Zurich & Switzerland & 16 \\
\hline Azapagic, Adisa & $\begin{array}{l}\text { https:// orcid.org/00 } \\
\text { 00-0003-2380-918X } \\
\text { Scopus Author ID: } \\
\text { 54967174100 }\end{array}$ & 53 & $\begin{array}{l}\text { The University of } \\
\text { Manchester }\end{array}$ & United Kingdom & 15 \\
\hline Freire, Fausto & $\begin{array}{l}\text { https:// orcid.org/00 } \\
\text { 00-0001-7269-5372 } \\
\text { Scopus Author ID: } \\
35611421600\end{array}$ & 25 & Universidade de Coimbra & Portugal & 15 \\
\hline Jolliet, Olivier & $\begin{array}{l}\text { https:// orcid.org/00 } \\
\text { 00-0001-6955-4210 } \\
\text { Scopus Author ID: } \\
\text { 7004103647 }\end{array}$ & 51 & University of Michigan & United States & 15 \\
\hline Rieradevall, Joan I. & $\begin{array}{l}\text { https:// orcid.org/00 } \\
\text { 00-0003-3360-6829 } \\
\text { Scopus Author ID: } \\
\text { 6508022118 }\end{array}$ & 44 & $\begin{array}{l}\text { UAB Institut de Ciència i } \\
\text { Tecnologia Ambientals }\end{array}$ & Spain & 15 \\
\hline
\end{tabular}

It is also noticeable that, although several institutions from China have high publication numbers, no scientists based in China appear on the list of authors with the most publications, as presented above in Table 3. One reason for this may be the fact that there are more Chinese scientists working in these fields, which results in a more distributed publication activity. In the U.S. and Europe, on the other hand, research activities on the topic of regional LCA seem to be more concentrated in a handful of institutions and this leads to the appearance of clusters of experts with a high number of publications on regional LCA. 
Table 5. Identified publications characterized by their affiliation/organization.

\begin{tabular}{ccc}
\hline Organization & Country & Number of Publications \\
\hline Chinese Academy of Sciences & China & 118 \\
ETH Zürich & Switzerland & 199 \\
Danmarks Tekniske Universitet & Denmark & 70 \\
Ministry of Education China & China & 63 \\
Corges teknisk-naturvitenskapelige universitet & Norway & 58 \\
Chalmers University of Technology & Sweden & 52 \\
Tsinghua University & China & 52 \\
European Commission Joint Research Centre & Belgium & 50 \\
Beijing Normal University & China & 48 \\
University of Chinese Academy of Sciences & China & 44 \\
KU Leuven & Belgium & 44 \\
Wageningen University and Research & Netherlands & 43 \\
China Agricultural University & China & 42 \\
Politecnico di Milano & Italy & 42 \\
University of Pittsburgh & United States & Sweden \\
Sveriges lantbruksuniversitet & France & 41 \\
Ecole Polytechnique Fédérale de Lausanne & Spain & 40 \\
Universitat Autònoma de Barcelona & Sweden & 39 \\
The Royal Institute of Technology KTH & United States & 36 \\
Arizona State University & & 36 \\
\hline
\end{tabular}

In terms of the country of origin of the published research work, the statistics reveal that a handful of countries stand out as primary publishing countries, even though research in the field of regional LCA is conducted in numerous countries. The United States (with 967 publications), China (741 publications), Italy (490 publications), Germany (414 publications), the United Kingdom (371 publications) and Spain (342 publications) stand out as the most prolific publishing countries in the area of regionalized approaches for life cycle assessment and life cycle management.

Figure 2 shows the concentration of the published papers based on their country of origin. The figures are expressed in terms of the percentage of publications per country out of the total papers included in this bibliometric analysis. The results show that the subject is particularly well-studied in the global north but is nevertheless widely spread throughout the world.

\section{PUBLICATIONS PER COUNTRY}

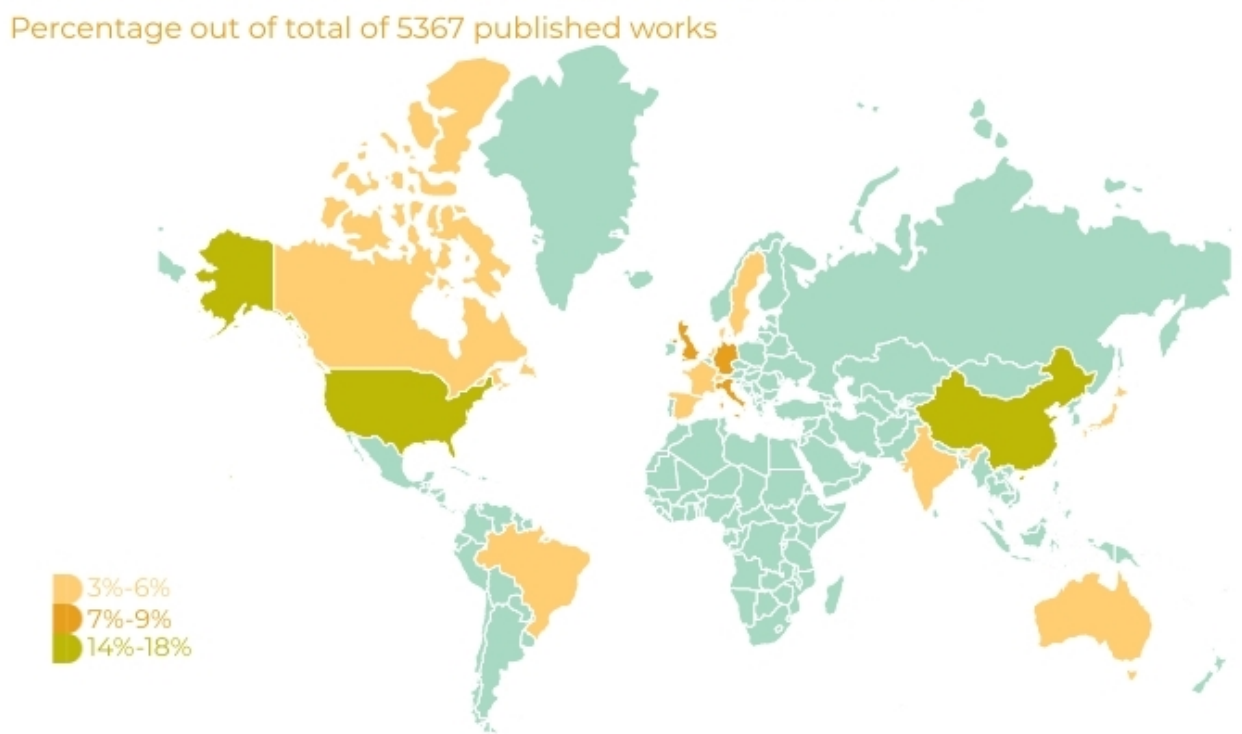

Figure 2. Publications per country, expressed as the percentage of the papers published between 1976 and 2020 found in the Scopus database (accessed on 3 February 2021). 


\subsection{Analysis of Application Areas}

The results presented in Table 6 show that around $20 \%$ of the papers on the subjects under analysis were published in just five journals.

Table 6. Leading journals/conference series for the publication of articles on regionalized life cycle assessment and management based on an analysis of the Scopus database, covering papers from 1976-2020 (analysis carried out on 3 February 2021).

\begin{tabular}{cccc}
\hline Journal/Conference Series & 2020 Journal Impact Factor & CiteScore 2020 & Number of Publications \\
\hline Journal of Cleaner Production & 9.297 & 13.1 & 434 \\
International Journal of Life Cycle Assessment & 4.141 & 7.8 & 290 \\
Sustainability (Switzerland) & 3.251 & 3.9 & 160 \\
Science of The Total Environment & 7.963 & 10.5 & 118 \\
Science & $/$ & 0.5 & 97 \\
Iop Conference Series Earth and Environmental & 10.204 & 14.7 & 96 \\
Resources Conservation and Recycling & 6.456 & 9.7 & 85 \\
Building and Environment & 5.879 & 10.9 & 76 \\
Energy and Buildings & 9.028 & 13.8 & 75 \\
Environmental Science and Technology & 6.946 & 12.8 & 75 \\
Journal of Industrial Ecology & 6.789 & 9.8 & 53 \\
Journal of Environmental Management & 7.145 & 11.5 & 50 \\
Waste Management & 14.982 & 30.5 & 4.5 \\
Ecological Indicators & 4.958 & 17.6 & 40 \\
Applied Energy & 9.746 & 39 \\
\hline
\end{tabular}

The first two journals, Journal of Cleaner Production and the International Journal of Life Cycle Assessment, together published around 13\% of the identified publications. This does not come as a surprise, since the former has traditionally been the journal chosen by multi-disciplinary teams and researchers for publishing life-cycle-related papers with a practical application in the industrial field. The latter is also one of the traditional journals for publishing methodological advances in the field of life cycle assessment. An interesting result is the emergence of two interdisciplinary journals such as Sustainability and Science of The Total Environment, which are also becoming frequent publishers of such papers. Sustainability illustrates how even a relatively new journal can become a discussion platform for this subject. This is one example of the relevance of the surgency of open access journals as scientific discussion platforms, which makes the published papers accessible to not only researchers and scientific institutions, but also to other stakeholders such as practitioners and regional managers.

Both the journal impact factor (2020) and CiteScore 2020 were included to facilitate the classification of the journals. The journal impact factor is a journal-level metric calculated from data that is indexed in the Web of Science Core Collection. The CiteScore measures the average number of citations that are made per document published in the serial (including all types of documents).

The evolution of the publishing activities on regionalized LCA across the various leading journals is shown in Figure 3. Just as with the general trend presented in Figure 1, there has been an exponential growth of published papers that began in the mid-2000s, which has now reached a publication rate of over 225 papers per year based on the figures for 2020 .

Since scientific journals are classified by subject category in the Journal Citation Reports (JCR) database, these subjects were utilized by Scopus to categorize the identified publications. Figure 4 sums up the research areas in which publications related to regional LCAs can be found. For this illustration, publications can be assigned to more than one category. 


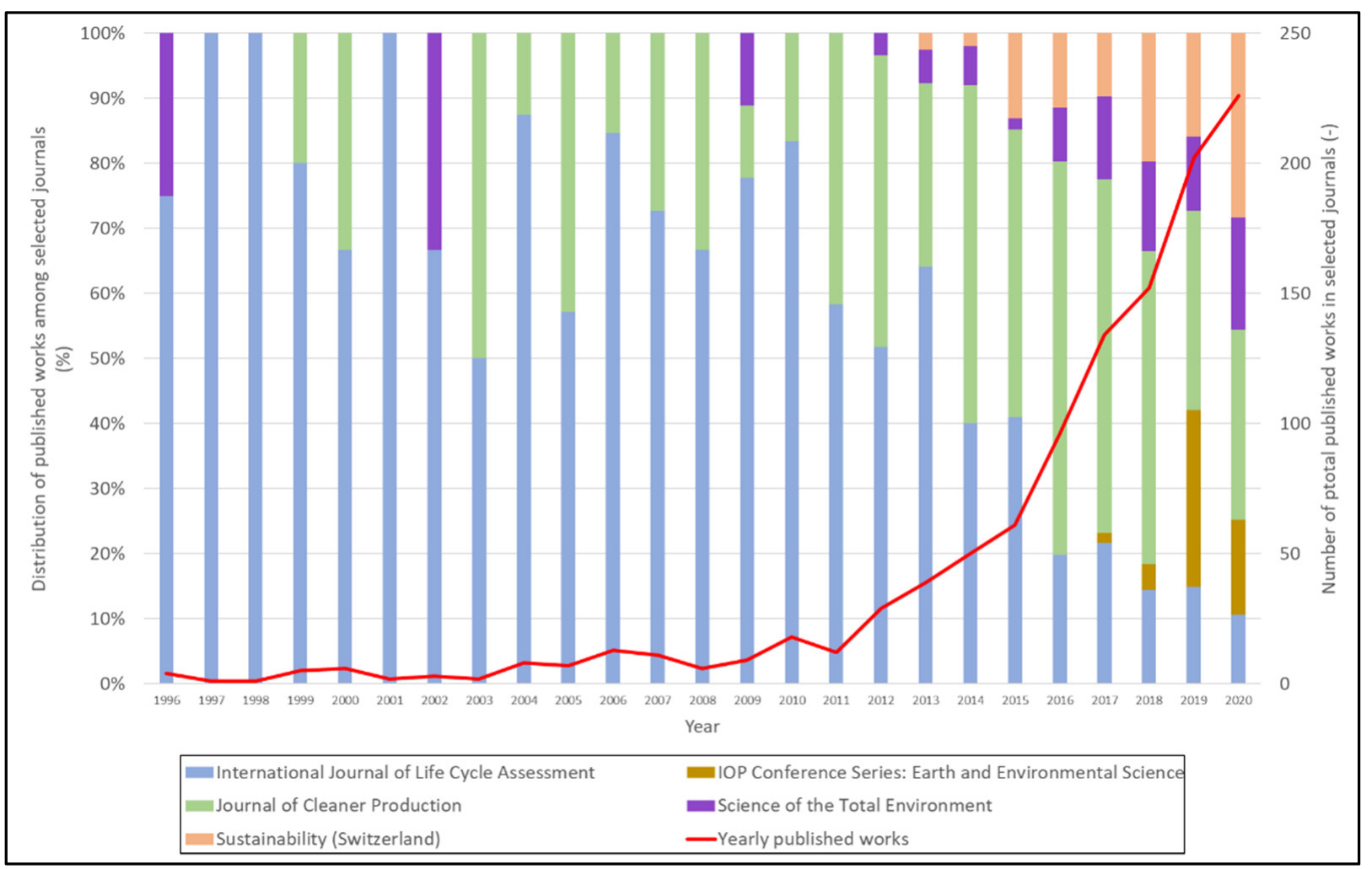

Figure 3. Evolution of the selected journals that publish papers related to regionalized LCA approaches from 1996 to 2020.

\begin{tabular}{|c|c|}
\hline Environmental Science & 3236 \\
\hline Engineering & 1910 \\
\hline Energy & 1252 \\
\hline Agricultural and Biological Sciences & 1028 \\
\hline Social Sciences & 869 \\
\hline Business, Management and Accounting & 598 \\
\hline Earth and Planetary Sciences & 468 \\
\hline Computer Science & 278 \\
\hline Materials Science & 271 \\
\hline Chemical Engineering & 240 \\
\hline Economics, Econometrics and Finance & 217 \\
\hline Chemistry & 174 \\
\hline Biochemistry, Genetics and Molecular Biology & 136 \\
\hline Medicine & 122 \\
\hline Mathematics & 121 \\
\hline Decision Sciences & 109 \\
\hline Physics (and Astronomy) & 96 \\
\hline Multidisciplinary & 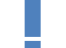 \\
\hline Arts and Humanities & ( \\
\hline Other Subject Areas & 76 \\
\hline
\end{tabular}

Figure 4. Characterization of the papers published from 1976-2020 based on the subject categories of the Scopus database.

There is a generally strong focus on engineering/science aspects with much fewer publications focusing on managerial, policy, social, territorial and economic issues. Most of the publications address the regional issues in an analytical manner, meaning that life cycle thinking is used to identify the potential impacts of the analyzed case studies. Some form 
of life cycle assessment methodology is used to do this. There are few examples of papers on life cycle management that support stakeholder activities. This represents a major gap in the knowledge transfer process for this research field.

\subsection{Results of the Co-Word Analysis}

Figure 5 visualizes the terms which occurred frequently in the titles and abstracts of the Scopus database (1392 publications). The size of the circles represents how often a term occurs, whereas the width of the lines represents the co-occurrence of terms. VOSviewer created six clusters, five large and one small. Table 7 also illustrates the most recurring keywords associated with all six identified clusters.

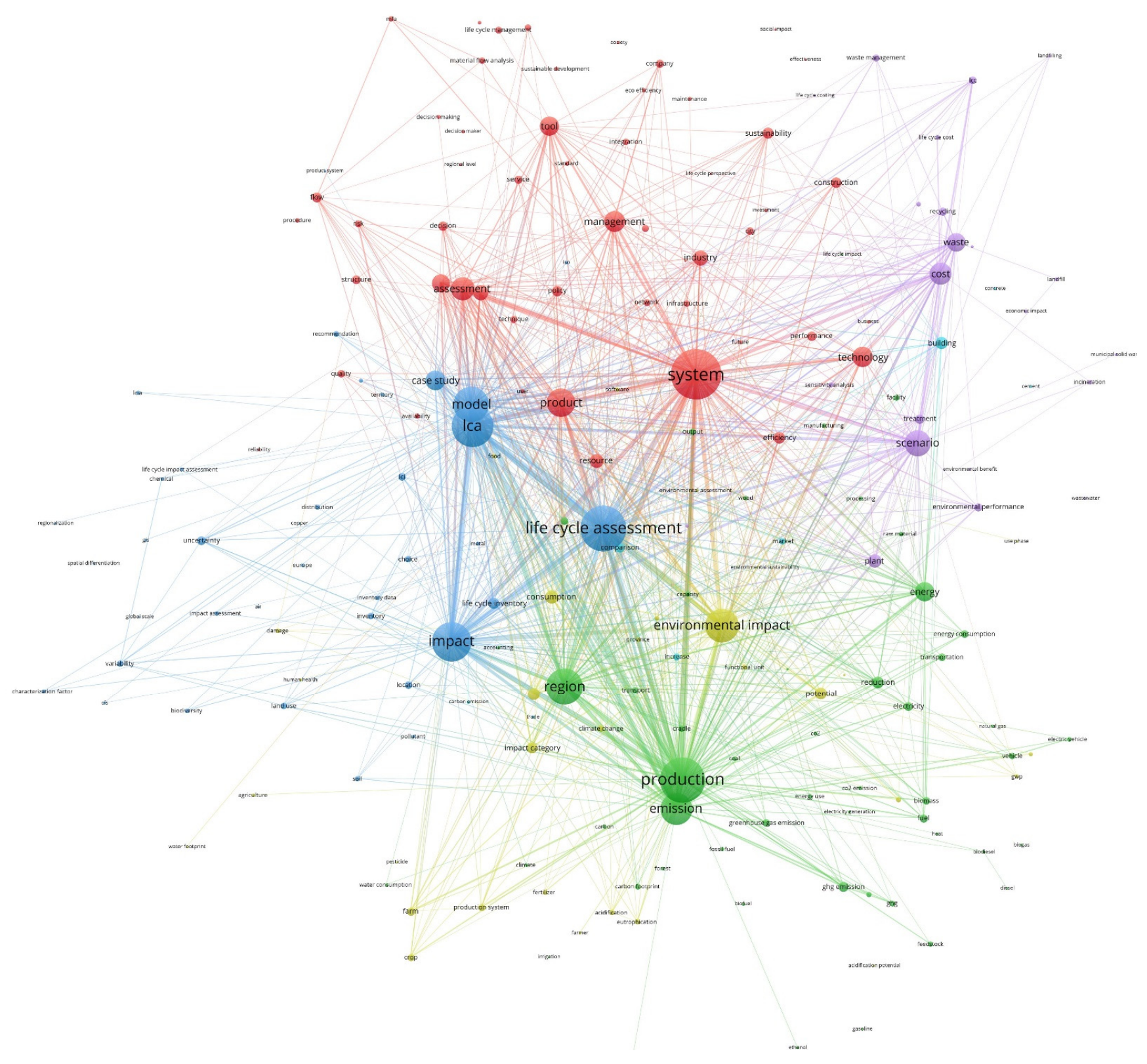

Figure 5. Graphical illustration of the co-word analysis carried out for the manuscripts resulting from queries \#1-\#13 (TI-TLE-ABS-KEY). For greater clarity, the most relevant keywords identified within the clusters are presented in Table 7. 
Table 7. Most relevant keywords associated with the six clusters identified in the bibliometric analysis.

\begin{tabular}{ll}
\hline Cluster & Keywords \\
\hline & Air, biodiversity, case study, characterization factor, chemical, choice, copper, distribution, Europe, \\
GIS, global scale, impact, impact assessment, inventory, inventory data, iso, land use, LCA, LCA \\
study, LCI, LCIA, life cycle assessment, life cycle impact assessment, life cycle inventory, location, \\
metal, model, pollutant, product system, regionalization, soil, spatial, differentiation, territory, \\
uncertainty, variability
\end{tabular}

Assessment, availability, business, circular economy, city, company, construction, consumer, decision, decision maker, decision making, eco efficiency, economy, effectiveness, efficiency, environment, flow, future, indicator, industry, infrastructure, integration, investment, life cycle management, life cycle

Cluster 2 (red) perspective, maintenance, management, material flow analyses, network, organization, performance, policy, procedure, product, quality, regional level, reliability, resource, risk, service, social impact, society, stakeholder, standard, sustainability, sustainable development, system, technique, technology, tool, user

Acidification, acidification potential, agriculture, climate change, consumption, crop, damage, environmental assessment, environmental burden, environmental impact, eutrophication, farm, Cluster 3 (yellow) farmer, fertilizer, food, functional unit, global warning, global warning potential, human health, human toxicity, impact category, pesticide, production system, province, software, use phase, water, water footprint

Accounting, biodiesel, biofuel, biogas, biomass, capacity, carbon, carbon, footprint, climate, co2, co2 emission, coal, cradle, diesel, electric vehicle, electricity, electricity, generation, emission, energy,

Cluster 4 (green) energy consumption, energy use, ethanol, facility, feedstock, forest, fossil fuel, fuel, gasoline, greenhouse gas emissions, heat, irrigation, land use change, life cycle impact, manufacturing, natural gas, output, policy maker, potential environmental impact, processing, production, raw material, reduction, region, supply chain, transport, transportation, vehicle, water consumption, wood

Cost, disposal, economic impact, economic performance, environmental benefit, environmental Cluster 5 (purple) performance, environmental sustainability, incineration, landfill, LCC, LCSA, life cycle cost, municipal solid waste, plant, recycling, scenario, sensitivity analyses, system boundary, trade off, treatment, waste, waste management, wastewater

Cluster 6 (light blue) Building, carbon emission, cement, comparison, concrete, increase, market, trade

The first large cluster, in blue, denotes the publications dealing with general case studies of (regional) LCA. The keywords associated with this cluster mostly deal with the LCA methodology, as would be expected. Interestingly, it is possible to identify further keywords such as "land use," "soil" and "location" as relevant indicators in these case studies, which complement the more general indicators such as general carbon emissions and pollutant discharges.

The second largest cluster, in red, corresponds to the area of systems and product analyses in the context of management approaches. This represents the results of case studies dealing with the application of tools for life cycle management or material flow analysis. The common focus of these publications seems to be on the application of these methods in industrial systems to assess the potential impact of technological approaches. In this cluster we observe a very weak link between the technological assessment and society and to the analysis of social impacts. A strong link, on the other hand, is observed in the third cluster (in purple), which deals with the subject of waste (management) and recycling (violet), particularly referring to life cycle cost methods and waste treatment options.

The fourth cluster, in green, combines references to energy aspects, production and emissions in a regional context. Various types of fossil and non-fossil energy sources are part of this cluster. From a systematic perspective, we found that, at a regional level, the role of biomass becomes relevant in energy-related case studies. In this regard, as expected in a systematic assessment of biomass-related issues, there is a strong link to the involvement of environmental sciences. However, there is still a lack of involvement of socioeconomic aspects, which are also part of the systematic analysis of the bioeconomy [51] and which should also be addressed in these types of publications. This indicates that there is still a 
gap in the use of socioeconomic tools, and this might be a triggering factor in not reaching the decision makers, as discussed in the previous section.

The yellow cluster is closely connected to this issue. This cluster addresses the regional LCA in the context of environmental impact and climate change. It shows a strong relation to the red system and management cluster. Again, in this cluster, there is no mention of the socioeconomic aspects of these systems.

In summary, the results show that the scientific knowledge about regional LCA is dominated by issues relating to waste, transport, energy and the building sectors. Numerous applications of LCA can be found in the building sector, as well as in the agricultural sector. Thus far, the applications of regional LCAs are related much more to regional human activities and not so much to regional natural resources. We can therefore conclude that the potential of regional or decentral supply chains has not yet been regarded as an issue in LCA studies. Finally, one shortcoming identified by this analysis is the lack of social and organizational issues covered in the publications we analyzed.

\section{Conclusions}

In this study, we have characterized the research history of regional LCA by illustrating its evolution between 1976 and 2020 based on the Scopus database. Over 5700 published scientific papers could be identified. Although many of them do not necessarily directly refer to "regional life cycle management" in their scope, this being a relatively new concept, they were nonetheless included in the evaluation due to the nature of the work carried out.

The results of this bibliometric analysis show that sustainable regional development is growing more and more dependent on the adoption of systematic and long-term criteria for decision making at different levels and that life cycle assessment has become an effective optimization tool for products and materials. While somewhat hampered by the lack of a common terminology concerning keywords related to 'regional life cycle methodologies', we observed a rapid growth in the publication activity on this topic in recent years. There is a strong concentration of research in this field as it is carried out in a rather restricted number of countries by specific institutions and published in a limited number of journals.

Our results show that the use of life cycle tools for regional sustainability management is still evolving. It has been held back by a lack of general awareness and application experience, as such techniques are more often applied in a business context than in regional management.

The co-word analysis indicated that the scientific knowledge base about regional LCA is strongly oriented towards the issues of waste, transport, energy and the building sector, which leads us to conclude that most of the regional studies are carried out within urban confines rather than within a "region". Moreover, we observed that the focus of these papers is predominantly on physical products oriented towards scientific or engineering applications rather than on the management of public issues and natural resources. This particular analysis did not identify publications on social and organizational issues. Moreover, there was a noticeable gap between MFA analyses and policymaking, suggesting the dominance of a research agenda rather than policy applications.

The results obtained in this bibliometric analysis have identified a gap between research and knowledge transfer to policymakers in the field of regional life cycle management. Although regional LCM has received increasing attention by researchers, there is little evidence of the results being transferred to policymakers and regional planners. Currently some EU-funded initiatives are closing this gap, but much more is needed to actually bridge it.

Finally, it must be stated that the outcomes of this study can serve as an indication of the trends in this scientific field, but it should be definitively augmented by a more comprehensive review. Such a review could use the results of this bibliometric analysis to structure its new search, which should not only search additional databases for scientific papers, but also include policy papers, technical reports and case studies. In addition, such a review should also include a thorough discussion on the quality of the published papers. 
Only then can we establish a better picture of the real status of the gap in knowledge transfer for the regional life cycle management reported in this analysis.

Author Contributions: Conceptualization, A.B., N.M. and F.B.; methodology, N.M. and A.B.; software, N.M.; validation, A.B. and F.B.; formal analysis, A.B., N.M. and F.B.; resources, D.T.; data curation, N.M.; writing — original draft preparation, A.B., N.M. and F.B.; writing-review and editing, D.T.; funding acquisition, D.T. All authors have read and agreed to the published version of the manuscript.

Funding: The research received financial support from the Helmholtz Association of German Research Centres through the PoF 4 program Changing Earth-Sustaining our Future, Topic 5 Landscapes of the Future.

Institutional Review Board Statement: Not applicable.

Informed Consent Statement: Not applicable.

Conflicts of Interest: The authors declare no conflict of interest.

\section{References}

1. Zhang, L.; Zhao, Y.N.; Zhang, X.L.; Du, H.R. Effect mechanisms of peasant relocation decision-making behaviours in the process of rural spatial restructuring: The case of Hotan Region, China. Sustain. Cities Soc. 2020, 63, 102429. [CrossRef]

2. Yang, Y.P.; Liu, Z.Q.; Chen, H.M.; Wang, Y.Q.; Yuan, G.H. Evaluating regional eco-green cooperative development based on a heterogeneous multi-criteria decision-making model: Example of the Yangtze river Delta region. Sustainability 2020, 12, 3029. [CrossRef]

3. Endriyas, M.; Alano, A.; Mekonnen, E.; Kawza, A.; Lemango, F. Decentralizing evidence-based decision-making in resource limited setting: A case of SNNP region, Ethiopia. PLoS ONE 2020, 15, e0236637. [CrossRef]

4. de Oliveira, C.P.; Neves, F.C.; Silva, A.R.; Araujo, R.A.D. Management tools for decision making: A study in micro and small enterprises engaged in acai marketing of Amazon region. Cust Agronegocio 2020, 16, 112-136.

5. Odei-Lartey, E.O.; Prah, R.K.D.; Anane, E.A.; Danwonno, H.; Gyaase, S.; Oppong, F.B.; Afenyadu, G.; Asante, K.P. Utilization of the national cluster of district health information system for health service decision-making at the district, sub-district and community levels in selected districts of the Brong Ahafo region in Ghana. BMC Health Serv. Res. 2020, 20, 514. [CrossRef]

6. Hildebrandt, J.; O'Keeffe, S.; Bezama, A.; Thrän, D. Revealing the environmental advantages of industrial symbiosis in woodbased bioeconomy networks: An assessment from a life cycle perspective. J. Ind. Ecol. 2019, 23, 808-822. [CrossRef]

7. Hildebrandt, J.; Bezama, A.; Thrän, D. Insights from the sustainability monitoring tool SUMINISTRO applied to a case study system of prospective wood-based industry networks in central Germany. Sustainability 2020, 12, 3896. [CrossRef]

8. Zhang, B.Q.; Su, S.; Zhu, Y.M.; Li, X.D. A LCA-based environmental impact assessment model for regulatory planning. Environ. Impact Asses. Rev. 2020, 83, 106406. [CrossRef]

9. Yildizbasi, A.; Ozturk, C.; Efendioglu, D.; Bulkan, S. Assessing the social sustainable supply chain indicators using an integrated fuzzy multi-criteria decision-making methods: A case study of Turkey. Environ. Dev. Sustain. 2021, 23, 4285-4320. [CrossRef]

10. Qi, Y.; Zhang, Y.; Jiang, H.; Hou, H.C.; Li, J.H. Life cycle assessment in urban territories: A case study of Dalian city, China. Int. J. Life Cycle Assess. 2019, 24, 1194-1208. [CrossRef]

11. Onat, N.C.; Kucukvar, M.; Halog, A.; Cloutier, S. Systems thinking for life cycle sustainability assessment: A review of recent developments, applications, and future perspectives. Sustainability 2017, 9, 706. [CrossRef]

12. Bare, J.C. Life cycle impact assessment research developments and needs. Clean Technol. Environ. 2010, 12, 341-351. [CrossRef]

13. Balkau, F.; Sonnemann, G. Synthesis-Life cycle approaches and perspectives for sustainable regional development. In Life Cycle Approaches to Sustainable Regional Development; Massari, S., Sonnemann, G., Balkau, F., Eds.; Routledge: New York, NY, USA, 2017; pp. 321-329.

14. Balkau, F.; Massari, S.; Sonnemann, G. Sustainable regional development in a life cycle context. In Life Cycle Approaches to Sustainable Regional Development; Massari, S., Sonnemann, G., Balkau, F., Eds.; Routledge: New York, NY, USA, 2017 ; pp. 9-14.

15. Bezama, A.; Cote, R.P.; Ioppolo, G.; Massari, S.; Mebratu, D.; Rydberg, T.; Sonnemann, G.; Balkau, F. Special Issue Life Cycle Management for Sustainable Regional Development. Available online: https://www.mdpi.com/journal/sustainability/special_ issues/LCM_Regional_Development (accessed on 1 September 2021).

16. Wegener Sleeswijk, A. Regional LCA in a global perspective. A basis for spatially differentiated environmental life cycle assessment. Int. J. Life Cycle Assess. 2011, 16, 106-112. [CrossRef]

17. Yang, Y.; Heijungs, R. A generalized computational structure for regional life-cycle assessment. Int. J. Life Cycle Assess. 2017, 22, 213-221. [CrossRef]

18. Wegener Sleeswijk, A. Regional LCA in a Global Perspective. Ph.D. Dissertation, Leiden University, Leiden, The Netherlands, 2010.

19. Hauschild, M. Spatial differentiation in life cycle impact assessment: A decade of method development to increase the environmental realism of LCIA. Int. J. Life Cycle Assess. 2006, 11, 11-13. [CrossRef] 
20. Potting, J.; Schöpp, W.; Blok, K.; Hauschild, M. Site-dependent life-cycle impact assessment of acidification. J. Ind. Ecol. 1998, 2, 63-87. [CrossRef]

21. Mutel, C.; Liao, X.; Patouillard, L.; Bare, J.; Fantke, P.; Frischknecht, R.; Hauschild, M.; Jolliet, O.; Maia de Souza, D.; Laurent, A.; et al. Overview and recommendations for regionalized life cycle impact assessment. Int. J. Life Cycle Assess. 2019, $24,856-865$. [CrossRef] [PubMed]

22. Gradin, K.T.; Bjorklund, A. The common understanding of simplification approaches in published LCA studies-a review and mapping. Int. J. Life Cycle Assess. 2021, 26, 50-63. [CrossRef]

23. Beemsterboer, S.; Baumann, H.; Wallbaum, H. Ways to get work done: A review and systematisation of simplification practices in the LCA literature. Int. J. Life Cycle Assess. 2020, 25, 2154-2168. [CrossRef]

24. Arendt, R.; Bachmann, T.M.; Motoshita, M.; Bach, V.; Finkbeiner, M. Comparison of different monetization methods in LCA: A review. Sustainability 2020, 12, 10493. [CrossRef]

25. Marx, H.; Forin, S.; Finkbeiner, M. Organizational life cycle assessment of a service providing SME for renewable energy projects (pv and wind) in the United Kingdom. Sustainability 2020, 12, 4475. [CrossRef]

26. D'Incognito, M.; Costantino, N.; Migliaccio, G.C. Actors and barriers to the adoption of LCC and LCA techniques in the built environment. Built Environ. Project Asset Manag. 2015, 5, 202-216. [CrossRef]

27. Mortimer, C. Enablers and Barriers to Adoption of Life Cycle Management; New Zealand Life Cycle Management Centre: Auckland, New Zealand, 2011; p. 35.

28. Simion, C.P.; Nicolescu, C.; Vrincut, M. Green procurement in Romanian construction projects. A cluster analysis of the barriers and enablers to green procurement in construction projects from the Bucharest-Ilfov region of Romania. Sustainability 2019, $11,6231$. [CrossRef]

29. Fuentes-Bargues, J.L.; Ferrer-Gisbert, P.S.; Gonzalez-Cruz, M.C.; Bastante-Ceca, M.J. Green public procurement at a regional level. Case study: The Valencia region of Spain. Int. J. Env. Res. Pub. Health 2019, 16, 2936. [CrossRef]

30. FSLCI. LCSS-Life Cycle Summer School. Available online: https:/ fslci.org/lcss / (accessed on 1 September 2021).

31. Interreg Europe. LCA4Regions-Improved Environmental and Resource Efficiency through Use of Life Cycle Instruments for Implemenation of Regional Policies of the European Union. Available online: https://www.interregeurope.eu/lca4regions / (accessed on 1 September 2021).

32. Ellen MacArthur Foundation. From Linear to Circular-A Global Learning Programme Designed for Professionals and Postgraduate Students. Available online: https://www.ellenmacarthurfoundation.org/our-work/activities/learning-opportunities/ from-linear-to-circular (accessed on 1 September 2021).

33. OECD. Green Public Procurement. Available online: https://www.oecd.org/gov/public-procurement/green/ (accessed on 1 September 2021).

34. OECD. Going Green: Best Practices for Sustainable Procurement; Organisation for Economic Co-operation and Development (OECD): Paris, France, 2015; p. 75.

35. UNEP. Sustainable Public Procurement. Available online: https://www.unep.org/explore-topics/resource-efficiency/what-wedo/sustainable-public-procurement (accessed on 1 September 2021).

36. Balkau, F.; Bezama, A. Life cycle methodologies for building circular economy in cities and regions. Waste Manag. Res. 2019, 37, 765-766. [CrossRef] [PubMed]

37. Bezama, A. Understanding the systems that characterise the circular economy and the bioeconomy. Waste Manae. Res. 2018, 36, 553-554. [CrossRef] [PubMed]

38. Bezama, A. Let us discuss how cascading can help implement the circular economy and the bio-economy strategies. Waste Manag. Res. 2016, 34, 593-594. [CrossRef] [PubMed]

39. Hawkins, D.T. Unconventional uses of on-line information retrieval systems: On-line bibliometric studies. J. Am. Soc. Inf. Sci. 1977, 28, 13-18. [CrossRef]

40. Thananusak, T. Science mapping of the knowledge base on sustainable entrepreneurship, 1996-2019. Sustainability 2019, 11, 3565. [CrossRef]

41. Huertas-Valdivia, I.; Ferrari, A.M.; Settembre-Blundo, D.; García-Muiña, F.E. Social life-cycle assessment: A review by bibliometric analysis. Sustainability 2020, 12, 6211. [CrossRef]

42. Guo, Y.-M.; Huang, Z.-L.; Guo, J.; Li, H.; Guo, X.-R.; Nkeli, M.J. Bibliometric analysis on smart cities research. Sustainability 2019, 11, 3606. [CrossRef]

43. de Souza, C.G.; Barbastefano, R.G. Knowledge diffusion and collaboration networks on life cycle assessment. Int. J. Life Cycle Assess. 2011, 16, 561-568. [CrossRef]

44. Chen, H.; Yang, Y.; Yang, Y.; Jiang, W.; Zhou, J. A bibliometric investigation of life cycle assessment research in the web of science databases. Int. J. Life Cycle Assess. 2014, 19, 1674-1685. [CrossRef]

45. Hou, Q.; Mao, G.; Zhao, L.; Du, H.; Zuo, J. Mapping the scientific research on life cycle assessment: A bibliometric analysis. Int. J. Life Cycle Assess. 2015, 20, 541-555. [CrossRef]

46. Estrela, S. I publish, therefore I am. Or am I? A reply to a bibliometric investigation of life cycle assessment research in the web of science databases by Chen et al. (2014) and mapping the scientific research on life cycle assessment: A bibliometric analysis by Hou et al. (2015). Int. J. Life Cycle Assess. 2015, 20, 1601-1603. 
47. He, X.; Yu, D. Research trends in life cycle assessment research: A 20-year bibliometric analysis (1999-2018). Environ. Impact Asses 2020, 85, 106461. [CrossRef]

48. Mahé, G. The indexation of scientific journals and the bibliometry: Examples with current tools. IRD/HSM Montpellier, France. 2017. Available online: https://horizon.documentation.ird.fr/exl-doc/pleins_textes/divers20-04/010077623.pdf (accessed on 1 September 2021).

49. Steinbeck, S.J. Management of Privately Owned, Large On-Site Sewage Systems. In Proceedings of the Fourth National Symposium on Individual and Small Community Sewage Systems, New Orleans, LA, USA, 10-11 December 1985; Available online: https: //www.ircwash.org/resources/proceedings-fourth-national-symposium-individual-and-small-community-sewage-systems (accessed on 1 September 2021).

50. Curran, M.A. Report on activity of task force 1: Data registry-global life cycle inventory data resources. Int. J. Life Cycle Assess. 2006, 11, 284-289. [CrossRef]

51. Bezama, A.; Ingrao, C.; O'Keeffe, S.; Thran, D. Resources, collaborators, and neighbors: The three-pronged challenge in the implementation of bioeconomy regions. Sustainability 2019, 11, 7235. [CrossRef] 